\title{
Legislative Technique as Basis of a Legislative Drafting System
}

\author{
Stijn Debaene, Raf van Kuyck and Bea Van Buggenhout
}

Institute of Social Law - Infosoc, Katholieke Universiteit Leuven, Belgium \{stijn.debaene, raf.vankuyck, bea.vanbuggenhout\} @aw.kuleuven.ac.be

\begin{abstract}
This contribution reports on a still ongoing research concerning a legislative drafting system named SOLON. ${ }^{1}$ The system is developed at the Institute of Social Law, Katholieke Universiteit Leuven, Belgium. SoLON is designed to support the implementation of the basic principles of legislative technique and is specifically based on the translation into computer algorithms of the 254 drafting guidelines of the Flemish government. In a first part specific attention will be paid to the Flemish guidelines. Secondly, the features and particular functions of the system will be discussed.
\end{abstract}

\section{Introduction}

In literature, over the last decade, there has been a growing interest for the possibilities of automated legislative drafting. This is mainly caused by a concern related to the often inadequate quality of legislation. A few examples of this quality problem are the growth of legislation, the inconsistency and the incomprehensibility of rules and statutes. These quality problems were the major impulses for the SOLON project.

SOLON is an automated legislative drafting system that will be used by the Flemish administration in the near future. The system is developed at the Institute of Social Law, Katholieke Universiteit Leuven, Belgium by order of the Flemish government and is inspired by foreign similar research concerning legimatics. ${ }^{2}$

The first part of the SOLON project consisted in determining quality criteria for legislation (Debaene et al. 1998). These criteria can be divided into two groups: on the one hand material criteria, mainly concerning the content of laws and on the other hand formal criteria, relating to, for example, structure and design.

Material and formal criteria are related to different steps in the drafting process. Material criteria rather concern the preparatory tasks in the drafting process like the problem definition, the problem analysis, the

1 This paper is a result of the project 'Solon - Systeem ter ondersteuning van legistiek en het ontwerpen van normen (System to support legal drafting)' by order of the Flemish Government, $n^{\circ}$ Bel96/06.

2 See footnote 13.

Stijn Debaene, Raf van Kuyck and Bea Van Buggenhout, 'Legislative Technique as Basis of a Legislative Drafting System', in: H.J aap van den Herik et al. (eds), Legal Knowledge Based Systems, J URIX 1999, The Twelfth Conference, Nijmegen: GNI, 1999, p. 23-34. 
generation of alternative solutions etc. Formal criteria refer to the phase in the drafting process wherein the norm content is transformed into a well designed bill.

Some examples of material criteria are clarity of the objectives, executability and enforceability, effectiveness and efficiency, consistency and compatibility with the principles of legal security and equality of rights. Formal criteria are, for example, the normative character, comprehensibility, publicity and regulation at the right level.

SOLON focuses on the phase in the drafting process wherein the norm content is transformed into formalised legal rules, shaped as articles of a bill or decree. This implies that the system has to provide the user with the necessary support to complete this phase in such a way that the drafted bill complies with the formal quality criteria for legislation.

The set of rules a drafter should observe to comply with the formal quality criteria can be referred to as 'legislative technique'. SOLON is a translation into computer algorithms of the legislative technique rules for the Flemish legislator.

In a first part of the paper we will try to define what legislative technique should be. In a second part, we will point out the actual content of legislative technique applicable to the Flemish legislator, which are the guidelines of the Flemish government. In a next part we take the step from legislative technique to legimatics, pointing out the different types of automated legislative drafting systems. Further, we will describe the specific features of SOLON and finally, the main part of this paper contains a description of the functionalities of SOLON.

\section{Content of the legislative technique}

It's common knowledge that the legislative technique rather concerns the form, shape and layout than the content of a bill. In literature, a lot of similar definitions (see e.g., Dickerson 1977; Kindermann 1979; Thornton 1987; Coremans \& Van Damme 1994; Gijssels 1994; Rescigno 1993) of the concept legislative technique can be traced. Bearing in mind these definitions we came to the following work definition of what legislative technique should be:

Legislative technique is (1) a technique that by the application of (2) a set of rules leads to (3) correct formulation and design of (4) a pre-set norm content, resulting in (5) a juridical-technical harmonisation of the norm in itself and in relation with other norms .

These five constitutive elements of the definition need to be clarified.

\subsection{Technique}

'Technique' means that legislative drafting and especially the phase wherein the norm content is transformed into a well designed bill shouldn't be considered an art but a technique that can be learned. ${ }^{3}$ Even so, there is a difference between experienced technicians capable of

3 About the possibility to learn drafting legal texts, see Bonnes \& Voermans (1996) and lest (1994). 
resolving complicated drafting issues, and less competent drafters, delivering poor results (Rescigno 1993).

\subsection{Set of rules}

Rules of legislative technique rules are to be derived from three sources. First, there are normative texts containing rules of legislative technique concerning, for example, the promulgation and enforcement of legislative texts. A second and more important source are administrative circular letters. ${ }^{4}$ These circular letters contain the 'guidelines for legislative technique'. Finally there are unofficial drafting guidelines ${ }^{5}$ and scientific contributions written by scholars.

\subsection{Correct formulation and design}

In our view legislative technique should concentrate on four major components: 1) design and structure of a bill; 2) linguistic usage and style of a bill; 3) composition and use of normative provisions; 4) composition and use of dependent provisions.

\subsubsection{Design and structure of a bill}

The rules concerning the design and structure of a bill are related to two aspects. Firstly they concern the general composition of the bill. From this point of view a bill consists of a title, an introductory part (header), the main part or body of the bill and the final (subscribing) part (footer).

Secondly, each of these parts is submitted to a further composition and layout. The title, for example, should contain the nature of the bill (statute, decree, regulation, etc.) and a short description of its content, again submitted to specific rules. The main part or body of the bill contains an exhaustive structure (definitions, field of application, new provisions and final provisions) and an exhaustive division (part, book, title, chapter, section, article, paragraph, etc.).

\subsubsection{Usage and style of a bill}

Legislative technique consists largely of rules for linguistic usage and style of a bill (Van der Velden 1985). Examples of linguistic usage are: the use of consistent (legal) terminology, suitability and unsuitability of certain expressions, the use of abbreviations, etc.

A first aspect of style is the linguistic form, e.g. the present tense has to be used (although the semantic character is imperative). A second aspect of the style is the sentence structure. Finally, legislative technique rules prescribe model clauses.

4 For instance for Belgium: Omzendbrief nr. C4/8001, 23 april 1982, Legistiek Opstellen van reglementaire teksten, B.S. 2 juni 1982; for Flanders: omzendbrief VR 97/4 van 4 maart 1997 van de minister-president van de Vlaamse regering.

5 See, for example, Coremans \& Van Damme (1994). 


\subsubsection{Composition and use of normative provisions}

Statutes are a consistent set of prescriptive, procedural, sanctioning and other provisions. Each of these types of provisions can be split up into different structural elements. The legislative technique should contain an exhaustive list of all provisions, their structural elements and the possible combinations 6 of provisions. ${ }^{7}$ There should also be guidelines concerning the use of each kind of provisions.

\subsubsection{Composition and use of dependent provisions}

In addition to normative provisions statutes also contain 'dependent provisions'. These provisions don't regulate human behaviour as normative provisions do, but determine the content and the effect of the normative provisions (Eijlander 1985). Examples of dependent provisions are definitions and referrals. Also for this type of provisions the legislative technique should contain a list of the most frequently used provisions and their structural elements. ${ }^{8}$ Again there should be guidelines concerning their use.

It's important to state that these four components are the ideal content of legislative technique. Until now only the first two components are incorporated in current rules dealing with legislative technique. The latter two components should be subject of further research before being included in legal guidelines.

\subsection{Pre-set norm content}

An important feature of legislative technique is that it only becomes operational when the content of the norm is already decided. 9 Legislative technique doesn't concern the preparatory tasks in the drafting process.

\subsection{J uridical-technical harmonisation}

The use of legislative technique should lead to a juridical-technical harmonisation within a specific act and in relation with other acts. Internal harmonisation refers, for example, to consistent terminology within a statute, correct internal referrals, etc. External harmonisation refers, for example, to consistent terminology in related acts and correct external referrals.

\section{Guidelines of the Flemish government concerning legislative technique}

\subsection{Nature, function and legal status of the guidelines}

The first guidelines concerning legislative technique in Belgium go back to 1960. They were issued by the federal government. In 1982 the federal gov-

6 For a research into these possible combinations, see Lachmayer (1975).

7 For such an approach see Biagioli (1997).

8 For a theory about referrals, see Karpen (1976).

9 Some authors say that form and content can't be distinguished that easily. See, for instance, Müller (1976). 
ernment updated its guidelines ${ }^{10}$, mainly to adapt them to constitutional changes that conferred legislative power to the regions. Next to this, the Flemish government elaborated its own set of guidelines ${ }^{11}$ on which SOLON is based.

The Flemish guidelines contain 254 directives and recommendations regarding legislative technique and procedural issues. In opposition to, for example, the Dutch guidelines 12 , they don't pay attention to the preparatory phase of the legislative process and don't deal with questions related to the necessity of legislative regulation, etc.

Generally speaking the function of the guidelines is to assist the draftsman in redacting a new bill. The goal of the legislative technique guidelines is to promote clarity and comprehensibility while the goal of the procedure guidelines is to guarantee a correct and fluent legislative process.

The Flemish guidelines are incorporated in an administrative circular letter, issued by the Flemish Prime Minister. This means that the guidelines merely have an internal effect and only apply to legislation that is produced by the government or its individual members. Members of Parliament are not bound by the guidelines.

\subsection{Content}

The 254 Flemish guidelines are divided into two major parts. The first 191 guidelines concern legislative technique sensu stricto (as defined above) while the next 63 guidelines are dedicated to the procedure that has to be followed throughout the legislative process.

Only the first 191 guidelines will be mentioned hereafter as SOLON only supports the legislative technique and has left aside legislative procedure.

These guidelines are grouped in four chapters. The first chapter (General remarks) contains 36 guidelines about the layout, the usage and style of the bill and the use of referrals.

The second and main chapter (Parts of a decreelaw, decree of the government and ministerial decree) contains 138 guidelines divided into 5 sections dealing with the title, the introductory part, the body, the final part and annexes of the bill.

Chapter 3 (Decree of the government to coordinate or codificate) consists of 12 guidelines concerning a specific kind of decree of the government, written to coordinate or codificate legislative texts. Finally, chapter 4 (Cooperative agreement) is dedicated to the collaboration treaties between the governments of the different regions and/or the central government.

10 Omzendbrief nr. C4/8001, 23 april 1982, Legistiek - Opstellen van reglementaire teksten, B.S. 2 juni 1982.

11 Omzendbrief VR 97/4 van 4 maart 1997 van de minister-president van de Vlaamse regering.

12 Besluit van de Minister-president, Minister van Algemene Zaken van 18 november 1992, Staatscourant 1992, nr. 230, tot vaststelling van de Aanwijzingen voor de regel geving. 


\section{$4 \quad$ From legislative technique to legimatics}

\subsection{Typology of systems}

Legimatics is the study of and the research into the possibilities of computer science for legislative drafting. In literature, several automated systems and methodologies to support legislative drafting are described. A distinction between two major types of systems can be made: 'semiintelligent drafting-support systems' and 'legislative analysis and review systems' (Voermans \& Verharen 1993). Although these types can not be completely separated, the analysis and review systems mainly try to assist the legislator in determining the consistency or the consequences of al ready existing (draft) regulations whilst semi-intelligent draftingsupport systems come into play when there does not yet exist a draft.

In the latter category apart from SOLON seven major existing systems can be mentioned: on the one hand LEDA and OBW in the Netherlands and on the other hand Lexedit (and its upgraded versions Lexedit 2 and Lexedit 3), Lexeditor (and its upgraded version Lexeditor 2), IRI-AL, Arianna and Norma in I taly.

The span of this paper does not allow a comprehensive discussion of all these legimatic projects but the main features and functionalities to be found (variously distributed) in the above-mentioned systems are the following:13

- support of preparatory legislative activities like the problem definition, the problem analysis, the generation of alternative solutions etc. The Preparatory (policy) Module in LEDA is a fine example of this feature.

- support of editing of normative texts within a word processor mainly by the support of the structural design of the normative text and the generation of normative formulas. This feature is strongly developed within the IRI-AL system.

- checks of the terminology, referrals etc. of the drafted text. This feature is a substantial part of the Lexedit system where consistency of the draft with the Italian drafting guidelines is checked.

- consultation and disclosure of the drafting guidelines ${ }^{14}$ on which each of these systems is based. In the Lexedit system, for example, the guidelines are included in a hypertextual hel pfile, called IPERINFLEX.15

\subsection{Specific features of SOLON}

SOLON has three specific features in its support function: it uses a different template for each legal document, provides text generation and supports information disclosure.

13 For a discussion of all features and functionalities, see: for LEDA and OBW, Voermans \& Verharen (1993) and Voermans (1995); for Lexedit and Lexedit 2, Biagioli \& Mercatali (1990) and Mercatali (1993); for IRI-AL, Baldini et al. (1995); for Arianna, Gioria \& Inzerillo (1998); for Norma, Guerra \& Pasetti (1998).

14 Leda, for example, is based on the "Aanwijzingen voor de regelgeving" issued by the Dutch government whilst Lexedit is based on the "Regole e Suggerimenti per la redazione di testi normativi" adopted by ten Regional Councils in Italy.

15 For a discussion of IPERINFLEX, see Mercatali (1995). 


\subsubsection{Different template for each legal document}

When the draftsman activates SOLON he has to select the desired legal document he wants to draft. He can choose between nine different legal documents: five categories of legislative documents (decree-law, decree of the government, ministerial decree, government decree to coordinate other regulations, and cooperative agreement) and four types of letters for demand for advice to the Council of State.

The study of the guidelines pointed out that the differences regarding layout and content between the documents are important enough to create a different template with specific drafting support for each of them.

\subsubsection{Text generation}

When drafting a new legislative document, text generation instruments have to be preferred over checks once the draft is completed (Mercatali 1995). The great quantity of model clauses in the guidelines and the fact that many Flemish draftsmen are domain experts that are not legally educated were other impulses to devel op the text generation feature of the system.

\subsubsection{Information disclosure}

Until now the Flemish draftsmen didn't make an intensive use of the guidelines when drafting a legislative document. Therefore SOLON discloses relevant drafting information from the guidelines the moment the specific information is needed.

\section{Functionalities of SOLON}

In this part we will describe the major functionalities of SOLON. Firstly, we describe how the system supports the structural design of different legislative documents. Next, the text generation functionality will be explained by the use of a few examples. This will be followed by an overview of the different ways the system provides the user with the specific information needed for the draft of a specified part of the document. Fianally we'll discuss how SOLON, apart from the technical legislative support, supports the legal content of a bill, mainly by the use of a text parser.

\subsection{Structural design}

A legislative document is drafted according to an exhaustive structure, prescribed by the drafting guidelines, and consisting of four major parts: the title, the introductory part , the body and the final part or footer of the bill.

Each of these parts is subject to a more specific structure. The introduction or header part of a decree of the government, for example, contains the following subparts: the introductory text The Flemish government', the legal ground, the motivation for the bill, the obtained advices, the ministers proposing the bill and the closing text 'after deliberation, concludes:'.

The body of the bill has to be structured in a double way: on the one hand a functional structure (in this order: definitions, field of application, new 
provisions and final provisions) and on the other hand the traditional hierarchical structure in parts, chapters, articles, paragraphs and so on.

The final part contains the date and place of promulgation and the ministers subscribing the bill.

To ensure a correct structural design, the basic design screen (the screen the user gets after selecting the desired legal document) is a template with pre-set text and layout suggestions. Shaded texts in the template represent the different (changeable) subparts of the introductory part or header. They are listed in the correct order, so the user drafting these parts (by clicking the shaded text and filling in the dialogue window(s) that follow(s), see further: 5.2. Text generation) will not make errors concerning the structural design of the introductory part.

The correct structural design of the final part is guaranteed the same way.

The functional structure of the body of the bill, being less formally structured, is made in a different way. Solon gives the user, when drafting a clause in the body of the bill, information about where that clause is to be situated. For example, inserting an executory clause will invoke an information window with the following text: 'An executory clause is to be situated in the last article of the bill. Do you want to proceed? (Y/N)'.

The hierarchical structure of the body of the bill is supported in two ways. For the division of the bill in parts, books, titles, chapters, sections and subsections, the user can select the desired division, specify its number and title. The system will then insert the division in the required layout.

For the division of the bill in articles and parts of articles, the system provides automated numbering. After inserting an article (by clicking a button), the other articles are automatically renumbered and internal referrals are updated. To distinguish between internal and external referrals, the system asks a confirmation to the user before it updates the referral.

\subsection{Text generation}

Some parts of a bill are quite formally structured and show certain similarities, like for instance the subscribing part, referrals, definitions, etc. Supporting the drafting of these parts is a very important feature of SOLON and is referred to as 'automated text generation' or 'text generation'.

The text generation is based on an analysis of the structure of these formal parts, which are then represented by the use of 'fill in fields'. These fields can be considered as the building blocks of the concerned part of the text.

There are two kinds of text generation in SOLON: text generation in the header and footer of the bill and text generation in the body of the bill. They correspond respectively with obligatory drafting support and drafting support on a voluntary basis.

\subsubsection{Text generation in the header and the footer of the bill}

Because of the formal structure of the header and the footer of the bill (see above), SOLON does not allow text in the header and the footer to be changed freely. Completing the title, the referral to advices or other required elements is only possible by the use of the automated text genera- 
tion, by means of dialogue windows (Obligatory drafting support.). Starting the support for the title can be done by clicking in the bill on the place of the title or by clicking a menu item or toolbar button. The same can be done for the other items of the header.

Next we will have a closer look at the title of a decree-law. The text generation for the other variable parts in the header and footer of the bill works in a similar way.

After the inventory of the different titles used in Flemish decrees-law, we were able to represent them as 66 different types (e.g. 'Ratification of treaty', 'Approval of budget'). Each type consists of fixed text and 'fill in fields'.

When the user activates the support for the title (of in this case a decreelaw), a window will appear in which the user can select the desired title (in this case for ratification of a treaty) in a listbox. It's also possible to indicate that one wants to draft a special decree-law, a programme decreelaw or a basic decree-law. If the user indicates one of these possibilities the text of the title is adapted.

The window contains two other boxes: one with a pre-set scheme of the selected title and one with an example of a completed scheme.

When the user selects the 'ratification of a treaty', the following scheme will appear in the window.

PROJECT OF DECREE-LAW IN ORDER TO RATIFY THE TREATY [BETWEEN_...] [CONCERNING_...] [AND_OF ...] [,_...]

The leftmost text before the first square bracket is the fixed part of the title. The four parts between the pairs of square brackets are the 'fill in fields'.

For every field in the title a dialogue window will appear (consecutively). Only after handling all 'fill in fields' the title can be brought into the bill.

The first 'fill in field' in the example is the field called 'contracting parties'. The user needs to specify this field by indicating the contracting parties of the treaty. SOLON will then automatically generate an exact formulation of the contracting parties (with commas, conjunctions and in capitals).

The three other fields are respectively the fields 'subject', 'annexes' and 'subscribing place \& date'.

\subsubsection{Text generation in the body of the bill}

The body of a bill contains the regulating part and is much less formal and structured than the header and the footer. Free changes must be possible. Therefore it is quite pointless to support the drafting of the body using the same techniques as for the header and the footer. A different type of text generation was implemented.

Typical examples of text generation in the body of the bill are amendment clauses. Text generation is started by clicking a menu item or tool bar button. The user has the choice to do so or not: he can alternatively (in opposition to the header and the footer) just type the clause.

When the user activates the text generation for the amendment clauses, a window will appear in which he has to select the desired amendment clause. He can choose between 'substitute', 'insert', 'add', 'suspend', 'abrogate', 'combinations', 'insert a previously suspended text', 'insert text instead of an annulated text' and 'amend federal statute'. 
When the user has selected the desired amendment clause subsequently a window will appear in which he will have to specify what type of division he wants to amend. He can choose between section(s), subsection(s) of an article, paragraph(s), title, sentence(s) and word(s).

Let's assume 'substitution of a paragraph' is chosen.

After clicking OK, the following text would be inserted in the body of the bill:

In article $\{\mathrm{nr}\}$ of external referral $\} \S\{\mathrm{nr}\}$ is substituted by the following:

"§ \{number\}. \{content\}".

The 'fill in fields' for the body of the bill are the pieces of text between brackets. The text between the brackets is the name of the field.

Once the scheme with 'fill in fields' is inserted in the body of the bill, clicking a toolbar button or pressing a shortcut key selects the next field. For complicated fields a window sustaining the completion of the field comparable to the windows for the fields used in the header and footer appears. For simple fields, for example, to fill in the number $\{n r\}$, the field just stays selected, so the user only has to type a number and jump to the next field.

\subsection{Information disclosure}

As stated above one of the main goals of SOLON is relevant information disclosure, meaning that drafting information concerning a specific topic becomes accessible at the moment it is needed.

The relevant information disclosure is guaranteed by four instruments: a) pop-up tips or information windows, b) hypertext links in the text of the bill, generated by the text parser, c) a help file and d) context-sensitive help.

Pop-up tips or information windows are drafting guidelines that 'pop up' (unasked) when the user is performing certain actions within SOLON. They reveal relevant guidelines regarding the part the user is working on or prompt the user to specify certain parameters.

The parser (see next point) generates among other things hypertext links to relevant guidelines when drafting the body of the bill to relevant guidelines. They invoke a tip when clicked on.

The third information disclosure instrument is the help file, consisting of the official drafting guidelines, however reordered and extended with additional information and explanations, and technical guidelines. The user can browse through the different chapters of the drafting guidelines or can search for support by the use of keywords or concepts.

The system also provides context sensitive help: every dialogue window contains a help button that invokes a help-screen, disclosing technical as well as substantive context-sensitive support and guidelines.

Finally, a 'tip of the day' can be set to appear every time the system starts.

\subsection{Support of legal content}

It would be incorrect to say that the previous functionalities just support formal aspects of legislative texts. Formal demands and quality of content cannot always be distinguished. SOLON contains a functionality that deals 
exclusively with the content of the legislative texts and more specifically with legal terminology: the text parser.

The text parser parses the body of the bill on the correct use of legal terminology. The parsers' aim is triple: firstly, changes of words or groups of words are suggested to the user. If the user agrees with the suggestion, the word or group is automatically replaced with the (better) alternative.

Secondly, the parser generates green coloured hypertext links in the bill, pointing to a tip or suggestion.

Thirdly, the parser generates red coloured hypertext links, indicating that that part of the text contains a mistake and invoking an explanatory error message when clicked on.

\section{Conclusions}

Semi-intelligent drafting-support systems such as SOLON have various advantages.

Firstly, the system helps the drafter to avoid mistakes and helps to draft bills faster and in a more efficient way. Also an implicit standardisation of the bills can be expected from the use of SOLON in government administration.

Another advantage is that the drafting guidelines will be more accessible, mainly due to context sensitive help, the possibility to search for keywords and concepts in the help file, the connection of different topics in the help file by means of hypertext links, and additional explanations to and reordering of the guidelines. For the same reasons one can argue that the guidelines will also be consulted in a more efficient way.

The more experienced legal drafter might feel the guidance SOLON offers through the drafting process, particularly the obligatory drafting support, as irritating. The option of the guiding character was chosen because many Flemish draftsmen are domain experts that are not legally educated. For them the guiding character, could probably be another advantage.

\section{References}

Baldini et al. 1995

P. Baldini, A. Capelli, G. Sartor, F. Tura, 'Prototipo di ambiente informatizzato per la redazione di testi legislativi' in: C. Biagioli, P. Mercatali \& G. Sartor (eds.), Proceedings of Legimatica: I nformatica per legiferare, Firenze/ Napoli: Edizione Scientifiche Italiane, 1995, pp. 185-199.

Biagioli 1997

C. Biagioli, 'Micro-ontologia funzionale della legge per il drafting e la cura degli ordinamenti', in: I nformatica e Diritto 1997, pp. 101-131.

Biagioli \& Mercatali 1990

C. Biagioli \& P. Mercatali, ‘Per la redazione automatica di testi legislativi', in: I nformatica e Diritto 1990, pp. 111-130.

Biagioli \& Mercatali 1993

C. Biagioli \& P. Mercatali, 'Strumenti automatici per redattare testi legislativi: Lexedit2 in Ambiente di normazione', in: Informatica e Diritto 1993, pp. 107-122.

Bonnes \& Voermans 1996 
J. Bonnes \& W. Voermans, Valt wetgeven te leren? Een vergelijkend onderzoek naar wetgevingsopleidingen', in: Regel Maat 1996, pp. 29-38.

Coremans \& Van Damme 1994

H. Coremans \& M. Van Damme, Beginselen van wetgevingstechniek en behoorlijke regel geving, Brugge: die Keure, 1994.

Debaene et al. 1998

S. Debaene, R. Van Kuyck, B. Van Buggenhout, 'Normen voor goede kwaliteit van wetgeving', in: R.W. 1997-1998, pp.833-847.

Dickerson 1977

R. Dickerson, Legislative drafting, Connecticut: Greenwood Westport, 1977.

Eijlander 1985

P. Eijlander, 'Proces, methode en techniek van wetgeving; elementen van wetgevingsonderwijs', in: Bestuurswetenschappen 1985, pp. 247255.

Guerra \& Pasetti 1998

R. Guerra \& G. Pasetti, 'Compilazioni, consolidazioni e strumenti legimatici', in: C. Ciampi \& E. Marinai (eds.), Proceedings of The Law in the Information Society, Firenze: IDG-CNR, 1998, CD-Rom.

Gioria \& Inzerillo 1998

M.L. Gioria \& D. Inzerillo, 'Un sistema e un ambiente di normazione per l'integrazione dei processi di conoscenza, produzione e divulgazione legislativa', in: C. Ciampi \& E. Marinai (eds.), Proceedings of The Law in the Information Society, Firenze: IDG-CNR, 1998, CD-Rom.

Gijssels 1994

J. Gijssels, 'Wetgevingstheorie. Wie normeert wat op staatsniveau?', in: M. Adams \& L.J. Wintgens (eds.), Wetgeving in theorie en praktijk, Antwerpen-Apeldoorn: Maklu, 1994, pp. 117-158.

lest 1994

K. lest, 'De vorming van wetgevingsjuristen', in: Ars Aequi 1994, pp. 579-582.

Karpen 1976

U. Karpen, 'Die Verweisungstechnik im System horizontaler und vertikaler Gewaltenteilung', in: J. Rödig, Studien zu einer Theorie der Gesetzgebung, Berlijn: Springer, 1976, pp. 221-240.

Kindermann 1979

H. Kindermann, Ministerielle Richtlinien der Gesetzestechnik: vergleichende Untersuchung der Regelungen in der Bundesrepublik Deutschland, in Osterreich und der Schweiz, Berlin-Heidelberg: Springer, 1979.

Lachmayer 1975

F. Lachmayer, 'Legistik und elektronische Datenverarbeitung', in: G. Winkler (ed.), Rechtstheorie und Rechtsinformatik, Wenen: Springer, 1976, pp. 221-243.

Mercatali 1995

P. Mercatali, 'I perinflex: A Hypertext for Legislative Drafting', I nformatica e Diritto 1995, pp. 85-109.

Müller 1976

G. Müller, 'Richtlinien der Gesetzestechnik in Bund und Kantonen', in

J . Rödig, Studien zu einer Theorie der Gesetzgebung, Berlijn: Springer, 1976, pp. 211-219.

Rescigno 1993 
G.U. Rescigno, ‘Dal rapporto Giannini alla proposta di manuale unificato per la redazione di testi normativi, adottata dalla Conferenza dei Presidenti dei Consigli regionali', Informatica e Diritto 1993, pp. 1332.

Thornton 1987

G.C. Thornton, Legislative drafting, London: Butterworth, 1987.

Van der Velden 1985

W. G. van der Velden, Van richtlijnen voor de wetgevingstechniek naar richtlijnen voor de regelingstechniek', Bestuurswetenschappen 1985, pp. 231-246.

Voermans 1995

W.J.M. Voermans, Sturen in de mist..., maar dan met radar. Een onderzoek naar praktisch haalbare vormen van computerondersteuning bij het ontwerpen van regelingen, Zwolle: W.E.J . Tjeenk Willink, 1995.

Voermans \& Verharen 1993

W. Voermans \& E. Verharen, 'LEDA: a semi-intelligent legislative drafting-support system', in: Legal knowledge based systems: J URIX '93: Intelligent Tools for Drafting Legislation, Computer-Supported Comparison of Law, J.S. Svensson, J.G.J. Wassink, B. Van Buggenhout (eds.), Lelystad: Koninklijke Vermande, 1993, pp. 81-94. 